Ágnes Szabára

László Ózsvári

\title{
3.4. ECONOMIC IMPACTS, CONTROL AND ERADICATION OF BOVINE VIRAL DIARRHOEA VIRUS
}

\begin{abstract}
Summary
Infections with Bovine Viral Diarrhoea Virus (BVD) are endemic in cattle populations worldwide and result in major economic losses; hence, many countries have begun BVD eradication programs. The authors estimated the losses caused by BVD, and the estimated annual losses in 2012 amounted to 4.5 million EUR in Hungary. In a dairy cattle farm with 1000 cows the acute clinical BVD could cause more than 166,264 EUR estimated yearly loss and the BVD-MD could be blamed for more than 10,203 EUR loss per year on average. The presented losses are probably underestimated as some disease effects are difficult to quantify, though they can indicate the income realizable in case of freedom from the disease, so can be the starting point of cost-benefit analysis of an eradication program. In the early $2000 \mathrm{~s}$, the control studies have shown that the seropositivity in northern and western European countries ranged between $1-95 \%$. Systematic BVD control aims to deliver a targeted reduction in the prevalence of BVD virus on sectoral, regional or national basis. In the Scandinavian countries, the eradication program is based on detecting and removal of PI animals without the use of vaccines. These programmes have been very successful, and by the late $2000 \mathrm{~s}$, the cattle herds' BVD infection in Scandinavia decreased below $0.1 \%$, but in several western and southern European countries, the prevalence still ranged between 35-90\%. In Hungary, the seropositivity was $40-50 \%$ in the $1970 \mathrm{~s}, 60-70 \%$ in the $1980 \mathrm{~s}$, and $95 \%$ in 1999 . The latest survey data in 2008 showed that the infection rate was $67.8 \%$ and $42.5 \%$ for herds and animals, respectively. The eradication has been obligatory in Lower-Austria since 2004, in Switzerland since 2008 and in Germany since 2011 with the use of vaccines. Mandatory eradication program started in Scotland in 2012, and began in Ireland in 2013 applying the Scandinavian method.
\end{abstract}

Keywords: BVD virus, economic losses, eradication programme

\section{Introduction}

Bovine Viral Diarrhoea Virus (BVDV) is the denomination of a heterogeneous group of viruses in the family Flaviviridae, genus Pestivirus with two accepted genotypes or species (BVDV-1 and -2), which are economically important pathogens that primarily infect ruminants (Varga et al., 1999). Prevalence of BVDV-1 and BVDV-2 vary across the world: BVDV-2 represents around $50 \%$ of the virus isolates in North America, whereas BVDV-1 dominates in Europe, with more than $90 \%$ (Lindberg et al., 2006). Most isolates of both viral species are well adapted to cattle and acute infections with such low-virulent strains generally go unnoticed unless there are other contributing factors. According to their ability to cause cytopathic effect $(\mathrm{CPE})$ in cell cultures, BVDV strains are classified as cytopathogenic (cp) or non- 
cytopathogenic (ncp) biotypes (Houe et al., 1995). Ncp is the most common naturally occurring biotype including BVDV-1 and BVDV-2 strains, and is the only biotype that can lead to persistent infections of BVDV. The cp biotype occurs much less frequently, cp BVDV strains were isolated almost exclusively from MD cases. Both $\mathrm{cp}$ and persisting ncp biotype can be simultaneously isolated from animals succumbing to MD. These isolates are called a "virus pair" (Meyers and Thiel, 1996, Ramsey and Chivers, 1953). BVDV virulence varies markedly, and due to a transient immunosuppression acute infections are often exacerbated by secondary infections. This is how BVDV plays its role in other disease syndromes, including respiratory and enteric conditions. Bovine viral diarrhoea virus also interferes extensively with reproductive functions. Depending on the time of infection, there may be a significant reduction in conception rates and an increased number of abortions, malformations, stillbirths or births of persistently infected calves. The latter are immunotolerant to the persisting virus.

Infection with BVDV can result in a wide spectrum of clinical diseases ranging from subclinical infections to a highly fatal form known as MD. In the typical cases the diagnosis is clear based on the observed clinical signs and lesions' characteristics of animal. The majority (70-90\%) of BVDV infections are subclinical. The likely source of these BVDV infections are cattle that are immunotolerant and persistently infected (PI) with ncp BVDV (Bálint, 2005).

The accurary of available diagnostic test is crucial for the success of a control program. For BVDV infection, several diagnostic test, aiming either to detect the virus itself, virus components, virus antigens or to detect viral-specific antibodies, are available (Varga et al., 1999).

In control programs, the performance of a diagnostic test, with regard to sensitivity and specificity, is highly dependent on the program's objectives. For example, antibody detection in bulk milk or pooled blood/serum/plasma is useful in initial screening for classification of herd status, but is not useful for monitoring a recently cleared herd to reconfirm its status or detect reinfection. Available diagnostic tools must be evaluated according to the specific objectives or phase in the control or eradication program at the level of the herd and of the region (Houe et al. 2006).

Virus isolation is usually considered the most reliable direct virus detection technique. Virus isolation requires cell culturing facilities which derived from kidney, testis or nasal turbinate epithelium of cattle. ELISA tests can be used for BVDV antigen detection. Antigen ELISAs have the advantage of being fast and inexpensive, obviating the need for cell culture facilities, and usually offering high sensitivity and specificity (Lindberg, 2003; Varga et al., 1999). The presence of BVDV ribonucleic acid (RNA) can be detected by reverse transcriptase-polymerase chain reaction (RTPCR). This technique offers high sensitivity, making it suitable for testing specimens with potentially low quantities of virus, as well as PI animals, or other biological materials (Belák and Pallagi-Pordány, 1991). The most commonly used antibody detection techniques are the virus neutralisation test (VNT) and antibody-specific ELISAs (Becher et al., 2003). 


\section{The economic losses caused by BVD}

The prevention of infectious diseases, which cause severe clinical signs and high mortality, is essential and clear for everyone. Most of the infectious diseases, which cause great economic losses, has been eradicated from the European countries (including Hungary) or their incidence could be decreased significantly. However, in the cattle herds in most of the European countries (including Hungary), there are still some widely spread infectious disease which primarily appear in chronic forms. These diseases do not often cause clinical symptoms and mortality, but the production parameters are weakening and over a long period can cause significant financial losses to the producers. In Hungarian cattle herds there are two viral diseases appearing mainly in their chronic forms which cause great economic losses; the Bovine Viral Diarrhoea and Mucosal Disease (BVD-MD), and the Infectious Bovine Rhinotracheitis (IBR).

The BVD is a major pathogen of cattle that causes significant economic losses worldwide in the cattle industry; for example in the Irish herds the annual total loss is estimated to be 102 million EUR (Byrne, 2010). An acute BVD outbreak has several negative effects on the production of dairy herds; it reduces the reproductive performance (more cows will remain empty), the milk production and the weight gain in calves, and increases the mortality rate, the risk of secondary infections and early culling (Ózsvári et al., 2001). The BVD virus can cause a wide range of lesions not merely in cattle with clinical signs but also in both infected cattle without any signs and in their progeny. In addition, the BVD virus has a strong immunosuppressive effect, which predisposes different diseases, such as pneumonia, mastitis, and diseases of bovine digits (Murphy, 2012).

An acute BVD outbreak caused an estimated average loss of 85 EUR per cow in Ireland (Byrne, 2010), 137 EUR per cow in United Kingdom (Bennett and Mawhinney, 1999), 74 EUR per cow in the Netherlands (Wentink and Dijkhuizen, 1990) and 59 EUR per cow in Denmark (Houe, 1994). The estimated average annual losses per cow caused by BVD are 34 EUR in Canada (Chi, 2002), 31 EUR in United Kingdom (Gunn et al., 2004) and 48 EUR in Ireland (SAC, 2010).

\section{The estimated annual losses caused by BVD in Hungary}

The BVDV occurs widely in the Hungarian large-scale dairy herds. The prevalence of the infected herds is estimated to be about 95\% (Kudron, 1999; Ózsvári et al., 2001). The annual risk of the introduction of the BVDV into intact herds, which are $5 \%$ of all herds, is between $30-50 \%$, that is, $1.5-2.5 \%$ of the total cattle population can have acute, clinical incidence of BVD yearly. The cattle of any age is exposed to the risk of infection but often certain age groups within a herd are affected by the disease (Kudron, 1999; Ózsvári et al., 2001).

The estimated losses caused by BVD in Hungary, based on the national cattle population, and the average Hungarian price and production data of the year 2012, are shown in Table 1. 
Szabára, Á. - Ózsvári, L.

Table 1. The estimated losses caused by BVD in Hungary (thousand EUR/year)

\begin{tabular}{|l|r|r|}
\hline \multicolumn{1}{|c|}{ Sources of losses } & Low* & High* \\
\hline Drop in milk production & 47.4 & 78.9 \\
\hline Abortion & 26.3 & 525.6 \\
\hline Mortality of cows & 38.9 & $1,296.4$ \\
\hline Premature disposal of cows & 97.2 & 890.8 \\
\hline Mortality of calves up to 1 year & $1,196.4$ & $4,785.7$ \\
\hline Total loss per national herd & $1,406.1$ & $7,577.4$ \\
\hline Total average loss per national herd & \multicolumn{2}{|c|}{$4,491.8$} \\
\hline Total loss per cow (EUR) & \multicolumn{2}{|c|}{13.7} \\
\hline Total average loss per cow (EUR) & \multicolumn{2}{|c|}{23.1} \\
\hline
\end{tabular}

*Depending on annual risk of infection of the BVD negative herds (30 or 50\%) and minimum and maximum effects of the disease on production (extreme values), low and high estimation of losses caused by BVD were carried out.

Source: own calculations

The annual estimated losses caused by BVD were approximately 4.5 million EUR on an average at national level, but if the rate of incidence is higher and the disease effects are more severe, the damage can come close to 7.6 million EUR. The loss per cow averaged 13.7 EUR yearly.

The estimated losses caused by both acute clinical BVD and BVD-MD complex in a herd with 1000 cows are shown in Table 2 and 3.

Table 2. The estimated losses caused by acute, clinical BVD in a dairy farm with $\mathbf{1 0 0 0}$ cows (EUR/year)

\begin{tabular}{|l|r|r|}
\hline \multicolumn{1}{|c|}{ Sources of losses } & \multicolumn{1}{c|}{ Low } & \multicolumn{1}{c|}{ High } \\
\hline Drop in milk production & \multicolumn{2}{|c|}{$9,627.0$} \\
\hline Abortion & 79.7 & $1,594.1$ \\
\hline Mortality of cows & $7,864.3$ & $157,285.7$ \\
\hline Premature disposal of cows & $19,648.9$ & $108,069.0$ \\
\hline Mortality of calves or cattle up to 1 year & $3,764.9$ & $14,985.7$ \\
\hline Total losses per herd & $40,966.4$ & \multicolumn{2}{|c|}{$291,561.6$} \\
\hline Total average losses per herd & \multicolumn{2}{|c|}{$166,264.0$} \\
\hline
\end{tabular}

Source: own calculations

Table 3. The estimated losses caused by BVD-MD in a dairy farm with 1000 cows (EUR/year)

\begin{tabular}{|l|c|c|}
\hline \multicolumn{1}{|c|}{ Sources of losses } & Low & High \\
\hline Abortion & 79.7 & $1,594.1$ \\
\hline Mortality of calves or cattle up to 1 year & $3,764.9$ & $14,985.7$ \\
\hline Total losses per herd & $3,826.1$ & $16,579.8$ \\
\hline Total average losses per herd & \multicolumn{2}{|c|}{$10,203.0$} \\
\hline
\end{tabular}

Source: own calculations 
The annual estimated losses per herd caused by acute BVD could be 166,264 EUR on an average, but if the disease effects are more severe, the damage can come close to 291,561 EUR. The annual losses resulting from chronic BVD were estimated to be 10,203 EUR per herd, but with severe disease impacts could exceed 16,579 EUR on herd-level.

The extent of losses is likely to be underestimated compared to the real damages caused by BVD, since many effects of the disease are difficult to be estimated. Having acquired the relevant data the losses coming from the immunsupression, reproductive disorders, subclinical effects and drug treatments can also become calculable.

The chronic BVD is also detrimental to the production parameters, hence, the control of chronic BVD infection can contribute to increase the profitability of dairy farms.

\section{Prevalance of BVD virus in Europe}

Infections with bovine viral diarrhoea virus are endemic in most cattle-producing countries throughout the world. Approximately $50 \%$ of all herds have PI animals, and $90 \%$ of all cattle become exposed during their lifetime. In endemic areas, a high correlation between BVDV prevalence and cattle density has been shown. BVDV occurs in most of the cattle-producing countries and causes significant economic losses to the cattle industry. This led in several countries to carry out epidemiological, as well as, cost/benefit studies and initiate eradication or control programs (for example Denmark, Finland, Ireland, Norway, Sweden). Before starting these programs the seroprevalence in the EU ranged from less than 1\% in Finland, through $19 \%$ in Norway, 46\% in Sweden, 64\% in Denmark to 95\% in England (Greiser et al., 2003). Between 2009 and 2010 a study was conducted about seroprevalance of BVD in the EU. According to study findings the prevalence was between $35-90 \%$ in France and Italy, less than $10 \%$ in Austria, also less than $0,1 \%$ in Sweden and Denmark and was below 0,01\% in Finland and Norway. Cattle herds of Great-Britain, Spain, Portugal, Germany, the Netherlands, Switzerland and Belgium had a BVDV prevalence rate more than 90\% (Di Labio, 2011).

In 2011 no BVD cases have been reported from Finland and Norway, and only two from Denmark, one of which was due to import of a BVDV vaccinated PI carrier from a non-free country. In Sweden two cases were detected in 2010 and one in 2011, all due to direct or indirect contact with herds still under investigation with suspected routes of transmission supported by molecular epidemiological investigations (Stahl and Alenius, 2012).

In Hungary, BVDV was deemed to cause severe respiratory, enteritis and abortion cases in the late 1950's (Áldásy and Szabó, 1959), but the virus was isolated only a few years later (Manninger et al., 1963). The seroprevalence of BVDV in Hungary was $40-50 \%$ in the $1970 \mathrm{~s}, 60-70 \%$ in the $1980 \mathrm{~s}$, and $95 \%$ in 1999 according to representative studies (Kudron, 1999).

In Hungary between 2006 and 2008 a nationwide representative survey was carried on the prevalence of BVDV. 16 Hungarian counties (out of 19) participated in the survey (except for Vas, Nógrád and Heves counties) and in these counties 
epidemiologically closed herds were randomly selected where there was no vaccination against BVD. In the selected cattle herds those animals were also randomly selected that did not show any clinical signs, and certainly did not have maternal antibodies. The laboratory tests were carried out by using the ELISA method, and 1,176 blood samples sent from 59 cattle herds. Out of the 1,176 samples 500 proved to be positive $(42.5 \%), 34$ were doubtful $(2.9 \%)$, while 642 were negative $(54.6 \%)$. Regarding the cattle farms, out of 59 herds sending samples for investigation there were 40 having at least one BVD positive animal $(67.8 \%)$, while among the blood samples of 19 herds no positive was identified (32.2\%). Among these latter herds there were several ones, where the samples were collected from old cows milking already through several lactation periods, therefore the seronegativity clearly indicates the BVDV free status of the given herd. Even among the positive cattle herds we have found a few where the prevalence of seropositivite animals was rather low $(<5 \%)$ (Mester, 2009).

\section{Eradication of BVD}

\section{Control and prevention}

At present, in most parts of Europe, BVDV is being controlled mostly on a voluntary basis. Control and eradication of BVDV is possible either with or without vaccines. Vaccines are available in many countries, but the take-up rate is very varied, from below 20\% up to 75\% (Moening and Brownlie, 2006). The strategy of control or eradication of BVDV depends on national regulations and financial resources. In the United Kingdom, Ireland, the Netherlands and Slovenia, only inactivated BVDV vaccines are licensed. The Scandinavian countries and Austria do not permit the use of BVDV vaccines, instead, large-scale eradication schemes are in place. The first largescale eradication schemes were launched in 1993-1994 in the Shetland Islands, Denmark, Finland, Norway and Sweden (Lindberg et al., 2006).

BVDV causes both transient and persistent infections and can escape from the host's immune responses during both events. Transient infection occurs in cattle of all ages. Oronasal infection results in transient viraemia and virus excretion is low before it is eliminated by a standard immune response. However, if infection occurs in a pregnant animal, the virus escapes by crossing the placenta to the foetus where it infects a wide variety of cells without killing them. Before day 120 of the gestation a foetus lacks a mature adaptive immune response; all viral antigens are accepted as its own and are forever seemingly ignored by the foetus' or the calf's cell-mediated and humoral adaptive responses. The foetus becomes immunotolerant to these viral antigens and will not respond to them throughout the rest of its life. The virus has simply escaped from the host's adaptive immune response, resulting in an animal that is persistenly infected (Nettleton, 2013). PI calf will continuously excrete millions of infectious virions every day of its life. Approximately $1 \%$ of one-year-old cattle are persistently infected. Transiently infected animals with high, long-lasting antibody levels and persistently infected animals with high levels of viraemia have provided important targets for diagnostic efforts (Houe et al., 2006). The most important factors of prevention are to detect and remove PI animals, avoid the introduction of BVDV 
and minimize the possibility of the introduction (Bálint, 2005). The basis of eradication without vaccines is the recognition and removal of PI animals from the herds. The Scandinavian countries and also some other regions in Europe are aiming at complete eradication of BVDV without use of vaccines (Lindberg, 2003).

In many countries, vaccines are used to control BVDV infections. Modern vaccination programs are designed not only to prevent clinical cases, but also to avoid viraemia and foetal infection. The inactivated, as well as, live vaccines may prevent foetal infection under controlled experimental conditions (Patel et al., 2002).

Classical BVDV vaccines are of two different types; live attenuated and inactivated (Bálint, 2005; Graham et al., 2004). The attenuated vaccines can clinically protect immune-competent animals against viral challenge. Live attenuated vaccines did not protect completely against congenital infection, and vaccination of PI cattle did not protect from developing MD after superinfection with a cp strain. If the vaccine strain is closely related to the ncp BVDV strain in the PI animal, early onset of postvaccinal MD can occur, as it was observed several times. If the vaccine strain is not closely related to the persistently infecting ncp strain, during replication, the live vaccine strain might recombine in the PI animal with the respective ncp wild type strains of BVDV, and this recombination can lead to the development of the delayed onset of MD. A further disadvantage of the attenuated live virus vaccines is their immunosuppressive effect (Bálint, 2005; Coggins et al., 1961; Kecskeméti et al., 1998; Simonyi and Bíró, 1967).

The inactivated BVDV vaccines are safe, the original strains and the possible other agents are completely inactivated, thus, reversion to virulence and recombination after vaccination with the field virus strain is impossible. The inactivated vaccines are not immunosuppressive, and do not infect the foetus. The drawback of these vaccines is that they are expensive and during inactivation immunogenic activity can decrease (Makoschey et al., 2004).

\section{Eradication methods}

Eradication of BVD is possible with selection, generation change, or use of inactivated vaccines (Varga et al., 1999). During the 1990's a systematic strategy to control BVDV, based on thorough knowledge of the epidemiology of the disease and, therefore, focused on prevention of foetal infection in early gestation, evolved within eradication programs in the Scandinavian countries (Lindberg and Alenius, 1999).

PI animals are the main source of infection within the infected herd, because they shed virus in very high concentrations in all fluids of the body throughout their life (Moen et al., 2005). PI calf is immunotolerant to BVDV, generally seronegative, and shed large quantities of virus throughout its life. The key role of PI animals in the maintenance of infection within herd is further supported by vast empirical evidence from the Scandinavian BVDV control schemes, showing that virus circulation essentially stops as soon as the last PI animal is eliminated from the herd (Lindberg and Houe, 2005). Experiences from the Swedish BVDV control program have shown that self-clearance, i.e. the process whereby an infection is eliminated from a population without intervention, is an important and frequent phenomenon that works in favour of BVDV control (Stahl et al., 2008). 
The Scandinavian strategy is based on three central elements: (1) biosecurity to avoid introduction of infection into BVDV free herds; (2) elimination of PI animals in infected herds to reduce virus circulation; and (3) continuous monitoring of free herds for early detection of reinfection (Lindberg and Alenius, 1999). The PI animals are seronegative, so in the Swedish method this has been used as a mean of identification, namely, after the individual serological tests, the seronegative individuals are virologically tested. There are other strategies for PI identification through direct virus detection, such as antigen testing of newborn calves by using e.g. ear-notch samples (Stahl and Alenius, 2012).

Herd diagnosis is defined as diagnosis that is based on testing samples from multiple representative individuals in a herd. The common goal is to detect the presence or absence of a given disease within the herd without testing every animal separately. Diagnosis can involve testing several animals individually, or the pooling of samples (serum/plasma/milk) from several animals before testing. For BVDV, the following tests have been used on herd level diagnosis; 1) detection of antibodies in bulk milk; 2) detection of antibodies in individual or pooled serum/plasma samples from young stock or in pooled samples of milk or serum/plasma from primiparous cows; and 3) virus detection in bulk milk. If the antibody test using bulk milk and the spot tests of young stock indicate the presence of PI animals in the herd, the next step is to identify individual PI animals. The methods of continuous monitoring used to confirm infection-free status are essentially the same as those used to establish initial herd status. However, the accuracy of the relevant tests depends to a large extent on three situational factors: time period immediately after removal of PI animals (clearance); time and mode of herd re-infection; and re-emergence of PI animals (Houe et al., 2006).

The Scandinavian BVDV control strategy had proved to be successful, thus, several other European countries have launched their control and eradication programs of BVD. Despite the different conditions at the start of the projects in terms of legal support, and regardless of initial prevalence of herds with PI animals, it took all countries approximately 10 years to reach their final stages (Stahl et al., 2008). LowerAustria launched a regional program on a voluntary basis in 1997, used the successful Scandinavian method. The program became compulsory in 2004 and extended to the entire country. In $200892 \%$ of all herds in Lower-Austria were certified as free from BVDV (Rossmanith et al., 2010).

The eradication program was launched in 2008 in Switzerland applying an alternative approach. The Swiss compulsory program is based on the identification and removal of PI animals through antigen testing of all newborn calves. They do not use serological testing. The alternative approach was needful because of the very high initial seroprevalence, the high cattle density, the frequent cattle movements and the use of shared summer grazing in mountain pastures. In the first phase, which is the eradication phase, all cattle in the country were sampled (ear-notch or blood) and tested for antigen. 1.5 million cattle were tested and more than 12,000 PI animals were detected. In the second phase, which was called the calf phase, almost 700,000 calves, which were in the uterus during the first testing, were tested within five days of birth, and around another 5,000 PI animals were identified. The third phase, which is the 
surveillance phase, is ongoing and carried out in accordance with the principles used in phase two. Until 2011, around 3.5 million animals have been tested and the prevalence of PI animals among newborn calves has decreased by 95\% (Di Labio, 2011).

A compulsory control program was introduced in all German states as of the $1^{\text {st }}$ of January 2011. There is obligatory testing of all calves, with direct virus detection from ear-notch samples using ELISA or/and RT-PCR. In the BVD free herds voluntary vaccination is being applied (Gaede et al., 2004). The vaccination includes a first immunization with an inactivated vaccine and 4 weeks later a second immunization with a modified live virus vaccine, which is an element of biosecurity (Moennig et al., 2005, Seeger et al., 2012). Mandatory eradication program launched in Scotland in 2012, in Ireland in 2013 applying the Scandinavian method (Barrett et al., 2011; Becher et al., 2003; Graham et al., 2011).

Large-scale control efforts have also implemented in Brittany in France (Joly et al., 2005), in the Netherlands (Moen et al., 2005), in Germany (Moenning et al., 2005) and in the Lecco and Como regions of Italy (Luzzago et al., 2004). Time-limited, projecttype control efforts have also been implemented in the Rome area (Ferrari et al., 1999), as well as, in Greece (Billinis et al., 2005) and Galicia in Spain (Lindberg at al., 2006).

\section{Conclusions}

It is clear that unless BVDV control efforts are harmonized across Europe, there will always be a threat of spreading BVDV, including the less prevalent BVDV-2 and any new types that may emerge across the continent. Efficient systematic control measures with or without the use of vaccines will provide the necessary protection. A challenge for the future is to find a joint platform where differences in needs and preconditions between member states can be accommodated. The OIE has added BVDV to its list, a strong signal that the disease has become an international priority.

The most important export markets of Hungary apply restrictive control measures as regards IBR and BVD, aiming at the prevention of import of infected animals and their animal products. The launch of a compulsory BVD eradication program in Hungary would mean a forward step to meet the animal health requirements of the international live animal and animal products trade. In order to achieve a successful eradication, national obligatory provisions should be applied to all cattle herds. Hungary would have a significant economic, environmental and animal welfare benefits if the disease was eradicated. One of the basic criteria for a successful eradication program is to detect and remove all the PI animals as soon as possible from the cattle herds. The rate of BVD infection increases with age. Hence those farmers, which are able to solve the detection and disposal of PI animals, and the separation of different age groups, can quickly complete the eradication among their calves.

Based on the results of the latest survey in Hungary the prevalence of BVDV is smaller than expected. Therefore, it is possible the make a herd replacement of a very infected farm by using BVD free breeding animals from free herds to help starting a national eradication program. 


\section{References}

1. Áldási, P.; Szabó I. (1959): Irányelvek a borjak gyomor-bélgyulladásának megelőzéséhez és gyógykezeléséhez, gyakorlati tapasztalatok és irodalmi adatok alapján. Magyar Állatorvosok Lapja, 14. pp. 325-329.

2. Bálint, Á. (2005): A szarvasmarha vírusos hasmenése vírusának molekuláris jellemzése, különös tekintettel a citopatogenitásra (PhD értekezés). SzIE Állatorvos-tudományi Doktori Iskola, Budapest

3. Barrett, D. J.; More, S. J. et al. (2011): Considerations on BVD eradication for the Irish livestock industry. Irish Vet. J., 2011. 64. 12.

4. Becher, P.; Avalos Ramirez, R. et al. (2003): Genetic and antigenic characterization of novel pestivirus genotypes: implications for classification. Virology, 2003. 311. pp. 96-104.

5. Belák, S.; Pallagi-Pordány, A. (1991): Bovine viral diarrhoea virus infection: rapid diagnosis by the polymerase chain reaction. Arch. Virol. Suppl., 1991. 3. pp. 181-190.

6. Bennett, R. M.; Mawhinney, I. (1999): The cost of BVD. BCVA Congress. Glasgow, 22-23. Oct. 1999.

7. Billinis, C.; Leontides, L. et al. (2005): Prevalence of BVDV infection in Greek dairy herds. Prev. Vet. Med., 2005. 72. pp. 75-79.

8. Byrne, N. (2010): BVD Case Study Teagasc Research Farm Ballydague. 2010. Available at: http://www.animalhealthireland.ie/pdf/BVDRoadshows-NoelByrne-s.pdf [15-11-2011].

9. Chi, J.; Van Leeuwen J. A. et al. (2002): Direct production losses and treatment costs from bovine viral diarrhoea, bovine leucosis virus, Mycobacterium avium subspecies paratuberculosis, and Neospora caninum. Prev. Vet. Med., 2002. 55. pp. 137-152.

10. Coggins, L.; Gillespie, J. H. et al. (1961): Attenuation of viral diarrhoea virus (strain Oregon C24V) for vaccine purposes. Cornell Vet., 1961. 51. pp. 539-545.

11. Di Labio, E. (2011): Critical success factors for rapid BVD-control at country level. In: Stahl, K. - Alenius, S.: ESVV Pestivirus Symposium. Hannover, Germany, September 25-28. 2011. pp. 23-25.

12. Ferrari, G.; Scicluna, M. T. et al. (1999): Bovine virus diarrhoea (BVD) control programme in an area in the Rome province (Italy). Vet. Microbiol., 1999. 64. pp. 237-245.

13. Fourichon, C.; L' Hotel, L. et al. (2009): Farmers motivations and obstacles to enter in and comply to a voluntary BVDV control plan. Fourth US BVDV Symposium, Phoenix, Arisona; http://www.ars.urda.gov/SP2UserFiles/Place/36253000/BVD2009/ [18-11-2012]

14. Gaede, W.; Gehrmann, B. et al. (2004): Eradication program for BVDV in Saxony-Anhalt (Germany). Revista Portuguesa de Ciencias Vet. Supl., 2004. 127. pp. 42-43.

15. Graham, D. A.; Calvert, V. et al. (2004): Birth of persistently infected calves in two herds using inactivated vaccines. Revista Portuguesa de Ciencias Vet. Supl., 2004. 127. 38.

16. Graham, D.; O'Flaherty, J.; Stott, A. (2011): Progress toward eradication of BVDV in Ireland. In: Stahl, K. - Alenius, S.: 8th ESVV Pestivirus Symposium, Hannover, Germany, September 25-28. 2011.

17. Greiser-Wilke, I.; Grummer, B.; Moennig, V. (2003): Bovine viral diarrhoea eradication and control programmes in Europe. Biologicals, 2003. 31. pp. 113-118.

18. Gunn, G. J.; Stott, A. W.; Humphry, R. W. (2004): Modelling and costing BVD outbreaks in beef herds. Vet. J., 2004. 167. pp. 143-149.

19. Houe H. (1994): Bovine virus diarrhoea virus: detection of Danish dairy herds with persistently infected animals by means of a screening test of ten young stock. Prev. Vet. Med., 1994. 19. pp. 241-248. 
20. Houe, H.; Baker, J. C. et al. (1995): Application of antibody titers against bovine viral diarrhoea virus (BVDV) as a measure to detect herds with cattle persistently infected with BVDV. J. Vet. Diag. Invest., 1995. 7. pp. 327-332.

21. Houe, H.; Lindberg, A.; Moenning, V. (2006): Test strategies in bovine viral diarrhoea virus control and eradication campaigns in Europe. Vet. Diagn. Invest., 2006. 18. pp. 427436.

22. Joly, A.; Fourichon, C.; Beaudeau, F. (2005): Description and first results of a BVDV control scheme in Brittany (western France). Prev. Vet. Med., 2005. 72. pp. 209-213.

23. Kecskeméti S.; Kiss I.; Tanyi J. (1998): A szarvasmarha vírusos hasmenésének leküzdése. Magy. Állatorv. Lapja, 1998. 120. pp. 323-328.

24. Kudron E. (1999): A nyugat-dunántúli szarvasmarha-állományok vírusos fertőzöttségének alakulása 1972-1996 között. Magyar Állatorvosok Lapja, 1999. 121. pp. 264-266.

25. Lindberg, A. L.; Alenius, S. (1999): Principles for eradication of bovine viral diarrhoea virus (BVDV) infections in cattle populations. Vet. Microbiol., 1999. 64. pp. 197-222.

26. Lindberg, A. L. (2003): Bovine viral diarrhoea virus infections and its control. Vet. Q.,25. pp. 1-16.

27. Lindberg, A. L.; Houe, H. (2005): Characteristics in the epidemiology of bovine viral diarrhoea virus (BVDV) of relevance to control. Prev. Vet. Med., 2005. 72. pp. 55-73.

28. Lindberg, A. L.; Brownlie, J. et al. (2006): The control of bovine viral diarrhoea virus in Europe: today and in the future. Rev. Sci. Tech. Off. Int. Epiz. 2006. 25. pp. 961-979.

29. Luzzago, C.; Frigerio, M.; Zecconi, A. (2004): BVD control program in Lecco and Como provinces (Italy): herd risk categories to modulate interventions. In: Proc. 2nd European Symposium on BVDV control, 20-22 October, Oporto, Portugal. Rev. Port Clenc. Vet., 99. (552), Suppl., 80 Available at:

http://www.fmv.utl.pt/spcv/PDF/pdf12_2004/552_39_82.pdf. [08-07-2013]

30. Makoschey, B.; Becher, P. et al. (2004): Bovine viral diarrhoea virus with deletions in the 5 -nontranslated region: reduction of replication in calves and induction of protective immunity. Vaccine, 2004. 22. pp. 3285-3294.

31. Manninger R.; Bartha A.; Juhász M.; Szent-Iványi T. (1963): Vizsgálatok a szarvasmarhák hazánkban előforduló, vírus okozta hasmenésének oktanáról. Magyar Állatorvosok Lapja, 1963. 18. pp. 225-227.

32. Mester A. (2009): Reprezentatív felmérés hazai szarvasmarha állományok BVDV fertőzöttségéről (TDK-dolgozat). SzIE Állatorvos-tudományi Kar. Budapest.

33. Meyers, G.; Thiel, H.-J. (1996): Molecular characterization of pestiviruses. Adv. Virus Res., 1996. 47. pp. 53-117.

34. Moen, A.; Sol, J.; Sampimon, O. (2005): Indication of transmission of BVDV in the absence of persistently infected (PI) animals. Prev. Vet. Med., 2005. 72. pp. 93-98.

35. Moennig, V.; Eicken, K. et al. (2005): Implementation of two-step vaccination in the control of bovine viral diarrhoea (BVD). Prev. Vet. Med., 2005. 72. pp. 109-114.

36. Moenning, V.; Brownlie, J. (2006): Position paper: vaccines and vaccination strategies. EU Thematic Network on BVDV control.

37. Murphy, N. (2012): Economic Impacts and Eradication of Bovine Viral Diarrhoea with special regards to Ireland. Thesis. Szent István University, Faculty of Veterinary Science, Dep. of State Vet. Med. and Agr. Econ., Budapest, 2012. 44.

38. Nettleton, P. (2013): Bovine viral diarrhoea virus: biology, diagnosis and control. Vet. Rec., 172. pp. 447-448.

39. Ózsvári L.; Bíró O.; Illés B. Cs. (2001): A szarvasmarhák vírusos hasmenése és nyálkahártya-betegsége (BVD-MD) okozta veszteségek nagyságának számszerüsítése. Magyar Állatorvosok Lapja, 123:(9) pp. 555-560. 
40. Patel, J. R.; Shilleto, R. W. et al. (2002): Prevention of transplacental infection of bovine foetus by bovine viral diarrhoea virus through vaccination. Arch. Virol., 2002. 147. pp. 2453-2463.

41. Ramsey, F. K.; Chivers, W. H. (1953): Mucosal disease of cattle. North. Am. Vet., 34. pp. 629-633.

42. Rossmanith, W.; Deinhofer, M. et al. (2010): Voluntary and compulsory eradication of bovine viral diarrhoea virus in Lower Austria. Vet. Microbiol., 2010. 142. pp. 143-149.

43. Scottish Agricultural College (SAC) (2010): Economics of Eradicating BVD from Ireland. http://www.animalhealthireland.ie/pdf/BVD\%20eradication\%20CBA\%20study\%20Ireland Report-Final.pdf [11-11/-2011]

44. Seeger, H. J.; Schwarzmaier, A.; Miller, T. (2012): BVD-bekampfung - Bilanz nach über 1 Jahr. Vet. Spiegel, 2012. 2. pp. 87-90.

45. Simonyi, E.; Biró J. (1967): Immunization experiments against hog cholera with the bovine viral diarrhoea virus strains Oregon C24V. Acta Vet. Acad. Sci. Hung., 1967. 17. pp. 5561.

46. Stahl, K.; Alenius, S. (2012): BVDV control and eradication in Europe - an update. Japanese J. Vet. Res., 2012. 60. pp. 31-39.

47. Stahl, K.; Lindberg, A. et al. (2008): Self-clearance from BVDV infections - a frequent finding in dairy herds in an endemically infected region in Peru. Prev. Vet. Med., 2008. 83. pp. 285-296.

48. Varga J.; Tuboly S.; Mészáros J. (1999): A háziállatok fertőző betegségei (Állatorvosi járványtan II.). Mezőgazda Kiadó. Budapest, 1999. pp. 413-417.

49. Wentink, G. H.; Dijkhuizen, A. A. (1990): Economic consequences of an infection with the bovine diarrhoea virus (BVD virus) in 15 dairy farms. Tijdschrift voor diergeneeskunde, 1990. 115. pp. 1031-1040. 